ELORE (ISSN 1456-3010), vol. $14-2 / 2007$.

Julkaisija: Suomen Kansantietouden Tutkijain Seura ry.

[http://www.elore.fi/arkisto/2_07/nit2_07.pdf]

\title{
KATSAUSARTIKKELI:
}

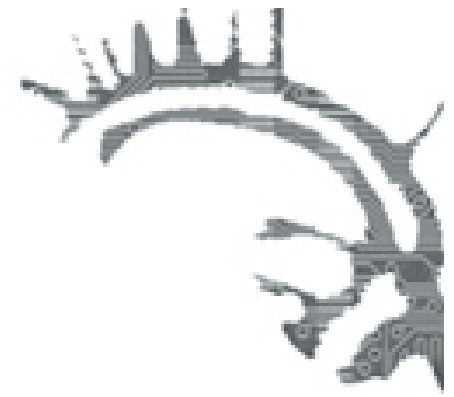

\section{TAITEILIJUUS JA TUTKIJUUS TUTKIVASSA TAIDEPROSESSISSA}

\author{
Liisa-Maria Nitovuori
}

Käynnissä olevassa folkloristiikan väitöskirjatutkimuksessani selvitän, millaisia merkityksiä sukupuolella on suomalaisessa nuorisotyössä. Aineistona käytän nuorisotyöntekijöiden suullisia haastatteluja. Yhtenä tutkimusmenetelmänä käytän kuvataiteellista työskentelyä. Ensimmäinen tilaisuus testata tämän menetelmän mahdollisuuksia tarjoutui, kun valmistelin kuvataiteilijan tutkinnon lopputyötäni Taidekoulu Maahan keväällä 2006. Korukielioppi-niminen teos syntyi halusta kokeilla, voiko väitöskirjaaineistoni kaltaisia haastatteluja käyttää myös taideteoksen tutkimusaineistona. Koska prosessi oli itselleni ensimmäinen laatuaan, tavoitteenani oli myös tarkastella omia roolejani, testata mahdollisuuksiani ylittää kahden ammattini välisiä raja-aitoja sekä arvioida kuvataiteellisen työskentelyn ongelmia ja mahdollisuuksia koko väitöskirjan kannalta. Tässä vaiheessa kyse oli muodollisesti enemminkin kuvataiteilijana pätevöitymisestä, mutta Korukieliopista oppimani kautta olen etsinyt ratkaisuja siihen, miten jatkossa käytän kuvataidetta myös varsinaisen väitöskirjatyön osana.

Aiemmin kulttuurien tutkijana tekemäni haastatteluanalyysit ovat olleet aina verbaalisia. Minua kiinnosti ajatus visuaalisesta analysoinnista ja tulkintojen pukemisesta materiaaliseen asuun. Suurin osa taiteellisesta tutkimuksesta on tapahtunut taidekorkeakouluissa. Näissä kuitenkin paitsi menetelmä myös itse tutkimuksen kohde on yleensä taiteellinen - tuote tai taideteos - ja tutkimuksen tavoitteena on tuottaa parempaa, ilmaisevampaa ja käytettävämpää taidetta tai designia (Scrivener 2002). Jos taidetta haluaa integroida tiedekorkeakoulussa suoritettavaan tutkimukseen, on valmiita sabluunoita käytössä vähän. Tämän artikkelin tarkoituksena on avata lisää tällaisen työskentelyn mahdollisuuksia. Pohdin, voisiko taidetta käyttää sellaisen tiedon tuottamiseen, joka liittyy itse teosta laajempiin kysymyksiin, kuten tässä tapauksessa sukupuolen merkityksiin nuorisotyössä. Miten tällainen ratkaisu voisi olla metodologisesti perusteltavissa kulttuurintutkimuksessa? Toiseksi käsittelen omia roolejani moniammatillisen työn tekijänä.

Korukielioppi käyttää lähtökohtanaan helsinkiläisessä Tyttöjen Talossa tehtyjä henkilökunnan haastatteluja. Keräsin aineiston kahta tarkoitusta varten: Korukielioppia varten sekä väitöskirjatutkimukseni koehaastatteluiksi. Haastatteluissa käytiin läpi haastateltavien ajatuksia työstään, ammatistaan ja naisidentiteetistään. Haastatteluja 
tehtiin kaikkiaan seitsemän, mutta yhden työntekijän siirryttyä pois Tyttöjen Talosta aineistoksi vakiintui kuusi puolituntista haastattelua. Purin haastattelut kirjalliseen muotoon, jota käytin jatkotyöskentelyn pohjana. Visualisoin haastatteluista tekemiäni tulkintoja korutaiteen keinoin: Valmistin jokaiselle haastateltavalle identiteettikorun, joka konkretisoi keskeisiä ammatti-identiteetin teemoja. Korut valmistettuani kuvasin ne haastateltavieni yllä. Keväällä 2006 työn dokumentaatio oli esillä Galleria Maa -tilassa Helsingin Albertinkadulla. Dokumentaatioon liittyi tietokone-esitys, joka koostui kuvista sekä teksteistä, niin haastattelukatkelmista kuin omista pohdinnoistanikin. Itse korut oli ripustettu seinälle tietokoneen ylle. Teokseksi kuitenkin käsitän koko prosessin itsessään.

\section{TytTöjen TALO TAITEELliSEn TUTKIMUKSEN KOHTEENA}

Tyttöjen Talo on ensimmäinen vain tytöille tarkoitettu nuorisotalo Suomessa. Se perustettiin vuonna 1999 esikuvanaan Xist tjejforum Tukholmassa. Tyttöjen Talo on kumppanuushanke, jonka osapuolina ovat Setlementtinuorten Liitto, Kalliolan Nuoret (paikallinen setlementtinuorisoyhdistys) sekä Helsingin kaupungin nuorisoasiainkeskus. Talon perusarvoihin ja -tavoitteisiin kuuluu tukea ja vahvistaa tyttöjen identiteettiä ja auttaa heitä kasvamaan itsensä näköisiksi naisiksi. Talo tarjoaa 13-25-vuotiaille tytöille ja nuorille naisille erilaisia aktiviteetteja, kuten vuorovaikutteisia tyttöryhmiä, harrastusryhmiä, mahdollisuuden oleskeluun avoimessa kahviossa, projekteja ja tapahtumia. (Laurent 2004, 31-36.) Haastatteluhetkellä talossa oli käynnissä kolme projektia, joista yksi, seksuaalikasvatus, on ollut Tyttöjen Talossa jatkuva työmuoto, vaikkakin rahoitus on ollut projektiluontoista. Muut käynnissä olleet projektit keskittyivät nuoriin äiteihin sekä monikulttuurisiin tyttöihin.

Tyttöjen Talo oli minulle tuttu aiemmasta tutkimus- ja arviointiprojektista (Nitovuori 2002). Näin tiesinkin, että talossa sukupuoli on jatkuvan pohdinnan ja määrittelyn kohteena. Ajatus vain tytöille tarkoitetusta nuorisotalosta on ollut niin uusi, että talon työntekijät ovat tottuneet vastaamaan kyselyihin ja epäilyihinkin. Toisaalta talon perusideologiaan kuuluu, että sukupuolta ei tulisi ottaa annettuna. Näin ollen ei ollut yllättävää, että talon työntekijöillä oli paljonkin ajateltuja mielipiteitä sukupuolesta ja myös sen roolista osana ammatti-identiteettiään. Haastattelujen ja koko prosessin läpivieminen olikin sikäli antoisaa, että Tyttöjen Talon henkilökunta oli niihin myönteisesti asennoitunut ja motivoitunut.

\section{METODOLOGISET PERUSLÄHTÖKOHDAT}

\section{Yhteisötaide ja tutkijan käymä dialogi}

Kuvataiteilijan opintojeni kuluessa tutustuin niin sanottuun yhteisötaiteeseen, jolla on yhtymäkohtia myös etnografiseen kenttätyöhön (ks. Kantonen 2005, 40-42). Tälle 
taidemuodolle on ominaista, että taideteos ei sijoitu vain valmiiseen tuotteeseen vaan vuorovaikutteiseen prosessiin. Kuten kenttätyötä tekevä kulttuurintutkija, myös yhteisöllisesti suuntautunut taiteilija voi viettää aikaa ihmisten parissa ja siellä tuottaa työtään ja sen aineistoa. Samalla kuvataide on laajentanut ilmaisuaan puhtaan visuaalisesta ja alkanut käyttää sellaisia termejä kuin ääni tai diskurssi (Kantonen 2005, 68).

Näiden yhtymäkohtien takia katsoin yhteisötaiteellisen lähestymistavan itselleni sopivimmaksi. Erityisesti kiinnostuin Grant Kesterin (2004) termistä dialogic art. Termi kuvaa taidemuotoa, jossa eri ihmisryhmien välinen dialogi on teos itsessään; kuvataiteilija toimii sen mahdollistajana, dokumentoijana ja usein osallistujanakin. En pyrkinyt luomaan puhtaan kesteriläistä dialogista taidetta, mutta minua kiinnosti dialogin nostaminen taideteoksi. Haastattelu on erityinen dialogin muoto, esimerkiksi hierarkkisempi kuin täysin vapaa keskustelu. Määrittelen kuitenkin myös haastattelut taideteoksi, ja perustelen tätä niiden uutta luovalla luonteella. Minulle kohtaamiset tuottivat uusia ajatuksia ja uutta tietoa ammatista, josta itselläni ei ole kokemusta tai ammattitaitoa. Haastatelluille kohtaaminen oli tilaisuus pysähtyä pohtimaan esittämiäni kysymyksiä.

Toisaalta näkemykseni mukaan haastattelu on itsessään myös tiedeteko. Kuten Maria Vasenkari (1996) toteaa, tiedon tuottaminen kulttuurintutkimuksen kenttätyössä, erityisesti haastatteluissa, on määriteltävissä pitkälti intersubjektiiviseksi. Tietoa ei ole olemassa objektiivisesti poimittavaksi; toisaalta se ei ole täysin subjektiivistakaan, sillä kenttätyössä tapahtuvassa kohtaamisessa ihmiset myös vaikuttavat toisiinsa. Siksi tieto itse asiassa syntyy dialogissa. Tällainen tiedon dialoginen tuottaminen on pitkälti neuvottelua ja yhteisymmärrykseen pyrkimistä.

Maria Vasenkari (1996, 93-94) puhuu Vincent Crapanzanoon viitaten dialogin triadisuudesta. Tällä tarkoitetaan sitä, että dialogin kolmantena osapuolena toimii aina aihetta koskeva esiymmärrys. Tämän kenttätyöprosessin kohdalla puhuisin ammatillisuuden dialogista. Kenttätyötilanteissa puhuivat ihmiset, joilla oli tietty ammattitaito, ja tämä pitkälti leimasi haastattelutilanteita. Keskustelukumppanina toimivat siis paitsi ihmiset itse, myös tietynlaiset idealisoidut nuorisotyöntekijät, naisja kulttuurintutkijat ja kuvataiteilijat. Nuorisotyötä tekevän ammattilaisen rooli oli myös se rooli, jossa tutkittaviani eksplisiittisesti lähestyin. Toki kolmansia osapuolia syntyi dialogiimme muutenkin, esimerkiksi sitä kautta, että tunsin osan haastateltavista ennestään jo melko hyvin.

\section{Avoimen keskustelun menetelmä ja teema-analyysi}

Käytännössä kenttätyössäni pyrin suuresti vapaata keskustelua muistuttaviin haastattelutilanteisiin. Haastattelu on harvoin täysin tasavertaista. Kenttätyössä ilmenee vallan epäsymmetriaa, ja sama on usein myös yhteisötaiteen ongelma (Kantonen 2005). Minunkin prosessissani, kuten tutkimuksissa yleensäkin, tietoa tuotettiin minun aloitteestani ja minun intresseistäni käsin. Pyrin minimoimaan tätä antamalla kunkin haastateltavan jossain määrin ohjata keskustelua itselleen luontevimpaan suuntaan. Haastattelut muodostuivatkin varsin yksilöllisiksi. Tässä suhteessa haastatteluni, ja 


\section{TAITEILJUUS JA TUTKIJUUS TUTKIVASSA TAIDEPROSESSISSA}

koko työni, eroavat jo alkumetreillä niistä tutkimushaastatteluista, jotka on voimakkaasti strukturoitu, mutta kulttuurintutkimuksessa käyttämäni avoimen keskustelun menetelmä on kuitenkin tuttu, ja sen etuna voidaan pitää holistisempaa lähestymistapaa (ks. Saarikoski 1996).

Näillä eväillä pystyin mielestäni mahdollistamaan tilanteen, jossa saatoin aidosti keskustella Tyttöjen Talon henkilökunnan kanssa molempia osapuolia kiinnostavista aiheista. Mielestäni se, että molemmat saattoivat esiintyä keskustelussa oman alansa asiantuntijana, oli omiaan purkamaan haastattelutilanteen epäsymmetriaa. Kohtaamista helpotti huomattavasti myös se, että olen itse aiemmin ollut työssä Tyttöjen Talolla ja minun tiedetään sitoutuvan moniin Talon arvoihin ja päämääriin. Tässä suhteessa työni poikkeaa vaikkapa Lea ja Pekka Kantosen (ks. L. Kantonen 2005) yhteisötaideprojekteista, joissa epäsymmetrian kysymykset muodostuivat varsin suuriksi.

Myöhemmin haastattelut muuntuivat puheesta kirjoitukseksi. Käsittelin haastatteluaineiston lukemalla sitä läpi ja merkitsemällä toistuvia ja keskeisiä teemoja. Näistä kokosin kunkin haastattelun osalta liuskan mittaisen tiivistelmän. Merkitsin ylös myös haastateltavien käyttämiä keskeisiä kielikuvia, sillä halusin mahdollisuuksien mukaan hyödyntää niitä visualisoinneissani. Tämä aineiston käsittelyvaihe oli itsessään jo tulkitseva ja muistuttaa suuresti kulttuurintutkijan tekemää teema-analyysiä.

Lisäksi olen käyttänyt Tyttöjen Talossa tekemiäni haastatteluja väitöskirjani koeaineistona, ja jo ennen Korukieliopin tekemistä kirjoitin niistä alustavaa tieteellistä analyysiä (Nitovuori 2006a). Tässä yhteydessä hain haastatteluaineistosta positioita, joita haastateltavat puheessaan ottivat suhteessaan tyttöihin. Analyysini mukaan kolme keskeistä positiota ovat samastuminen, erottuminen ja diversiteetin korostaminen. Samastumista tuottaa osin essentialisoivakin naispuhe, kun taas erottautuvaa positiota käyttäessään haastateltavat toivat itseään esiin ennen kaikkea aikuisina ja ammattilaisina. Diversiteettiä korostava positio toimii ikään kuin sillanrakentajana näiden välillä; sen kautta haastateltavat myöskin sulauttivat puheeseensa Talon ideologiaa.

Tärkeimpänä erona Korukieliopin ja tekemäni tieteellisen analyysin välillä näkisin, että jälkimmäisessä tarkastelin aineistoa kokonaisuutena, kun taas edellisessä käsittelin kutakin haastattelua erikseen. Kuitenkin jo tehty yleisemmän tason analyysi ei voinut olla vaikuttamatta näihin yksilöistä tekemiin tulkintoihin, vaan nämä keskeisiksi analysoidut teemat olivat jatkuvasti mielessäni ja näkyvät myös visualisoinneissani.

\section{Mihin ITSE PAIKANNUIN PROSESSISSA?}

Paikan määrittely prosessin alkuvaiheessa oli vaikeaa, ja osin tämä muodostuikin tutkimuskysymykseksi itsessään. Käytännössä otin sekä tutkijan että taiteilijan rooleja, jotka painottuivat tilannekohtaisesti. Taidekoulukontekstissa paikannuin selvästi taiteen kenttään, ja sieltä saatu ohjaus ja palaute muokkasivat työtäni visuaalisempaan suuntaan. Esimerkiksi tekstiosuudet jätin näyttelyssä esillä olleessa työssä lyhyiksi. Vastaavasti tutkijan roolini on korostunut niissä prosessin vaiheissa, joissa olen esi- 


\section{LIISA-MARIA NitOVUORI}

tellyt työtäni tiedeyhteisölle (esim. Nitovuori 2006a; 2006b). Niinpä työn esittäminen on saanut stereotyyppisiäkin muotoja, tiedeyhteisölle puhun sanoin, taideyhteisölle kuvin.

Haastattelutilanteissa Tyttöjen Talolla taas esittelin projektini tutkimuksen ja taiteen yhdistelmäksi, mutta haastattelutilanteessa esiinnyin pikemminkin tutkijana. Lisäksi minut tiedettiin Talolla tutkijaksi, kun taas kuvataiteilijan roolini ei siellä aiemmin ollut tullut juurikaan esiin. Kuitenkin myöhemmin palasin Talolle esittelemään työni tuloksia; kun minulla oli visuaalista näytettävää, korostui taiteilijan roolini aiempaa enemmän.

Pyrin itse tietoisesti olemaan samalla sekä tutkija että taiteilija niin, että molemmat roolit seuraisivat mukanani kaikissa työn vaiheissa. Ehkäpä osuvinta olisi kuitenkin käyttää tekemisestäni Pirkko Anttilan $(2005,10-11)$ taidealojen tutkimukseen ehdottamaa termiä "tutkiva taiteellinen toiminta". Tällainen toiminta ei edellytä jatkuvaa vahvaa kaksoisroolia vaan osaamisen ammentamista molemmista rooleista.

Pyrin joka tapauksessa pitämään roolini mahdollisimman läpinäkyvänä. Tässä suhteessa projektini ei olekaan tyypillinen yhteisötaideprojekti. Yhteisötaide pohjautuu sosiaaliselle siteelle osallistujien välillä; minä työskentelin pitkiä aikoja myös yksin. Yhteisötaide laajemminkin pyrkii häivyttämään (taiteilija)subjektin osuutta tuomalla esiin muiden prosessiin osallistuneiden ääntä (ks. Kantonen 2005, 36-48). Oma näkemykseni taiteilijasubjektin esillä pitämisestä on, että sekin on mahdollista tehdä sensitiivisesti. Sama koskee tutkijasubjektia. Erityisesti naistutkimuksen kautta olen omaksunut näkemyksen, että liika subjektiuden häivyttäminen saattaa ylläpitää objektiivisuuden harhaa. Halusin Korukieliopissa siis pitää subjektin osuuden selvästi artikuloituna, jotta omat tulkintani olisivat mahdollisimman läpinäkyviä. Teosdokumentaatiota valmistaessani ratkaisin kysymyksen käytännössä visuaalisesti niin, että sijoitin haastattelusitaatit selvästi erilleen omista kommenteistani ja pohdinnoistani. Koin tämän tärkeäksi myös siksi, että työ tulkitsee haastateltavien identiteettejä.

\section{KORUKIELIOPIN RAKENNE}

Korukielioppi-teos koostuu viidestä osa-alueesta, jotka risteävät teoksessa moneen otteeseen. Ensimmäinen osa ovat siis haastattelut, joissa mahdollistui kohtaaminen minun ja Tyttöjen Talon työntekijöiden kanssa. Korukieliopin kokonaisuus pohjautuu pohdinnoille, joita olemme haastateltavien kanssa dialogissa tuottaneet.

Toinen osa on taustatieto. Itselleni uutta tietoa hankin erityisesti esineistä ja esinekulttuurista, mutta lisäksi olen hyödyntänyt aiempaa tietämystäni esimerkiksi naiseuteen liitetyistä kulttuurisista merkityksistä. Tutustuin tässä vaiheessa pääasiassa folkloristiseen, kansatieteelliseen ja antropologiseen tutkimukseen (esimerkiksi muotoilun ja taiteen tutkimuksen kustannuksella). Tämä taustatieto on monin tavoin sulautunut osaksi koko teosta, mutta ei lopulta tullut siinä kovin eksplisiittisesti esiin.

Kolmas ovat materiaaliset tuotteet, tässä tapauksessa korut. Korujen valinta valmistettavaksi tuotteeksi ei ollut itsestään selvä; konkreettista tuotetta ei olisi myöskään 


\section{TAITEILJUUS JA TUTKIJUUS TUTKIVASSA TAIDEPROSESSISSA}

tarvittu lainkaan, jos olisin päätynyt vaikkapa käsitetaiteelliseen lähestymistapaan. Päätymistäni juuri koruihin selvitän tarkemmin tuonnempana. Koruja valmistin siis kaikkiaan kuusi. Valmistusprosessiin kuului käytettävän materiaalin valinta, etsiminen ja sen sisältämien merkitysten huolellinen pohtiminen. Tässä vaiheessa palasin toistuvasti haastatteluaineistoon ja niistä tekemiini alustaviin tulkintoihin. Oli tarpeen löytää materiaali ja työstämistapa, joilla voisin parhaiten ilmaista tulkintojani; toisaalta konkreettinen korujen valmistus auttoi myös kiteyttämään sitä, mitä työlläni halusin sanoa. Varsinainen käsityö vei lopulta hyvin vähän aikaa, ja valmistin korut varsin yksinkertaisilla tekniikoilla.

Työn neljäs osa on uusi kobtaaminen, jolloin vein korut Tyttöjen Taloon työntekijöiden nähtäviksi ja arvioitaviksi. Uusi kohtaaminen oli mahdollisuus uuteen dialogiin. Olin valmistautunut siihen, että joku työntekijöistä esimerkiksi haluaisi sanoutua irti tekemistäni visuaalisista tulkinnoista, mutta korut otettiin Talolla erittäin hyvin vastaan. Osasyynä oli varmasti se, että korut koettiin esteettisesti onnistuneiksi, mutta ne myös herättivät keskustelua ja uusia tulkintoja. Kuvasin haastateltavia koruineen, ja he halusivat myös esitellä ja kommentoida niitä toisilleen. Vain yhden työntekijän tapasin Talon ulkopuolella, koska hän oli hiljattain jäänyt äitiyslomalle.

Viides osa on dokumentaatio. Sen kuvallisena osana toimivat valokuvat, joita otin koruista sekä itsenäisesti että käyttäjiensä yllä. Otin myös runsaasti kuvia esimerkiksi valmistusvaiheesta, materiaaleista ja valmiista koruista itseni yllä, mutta näistä kuvista mikään ei lopulta päätynyt julkisesti esiteltyyn dokumentaatioon. Tietokoneesitykseen valikoin kuvia ja haastattelusitaatteja sekä kirjoitin ylös omia pohdintojani ja tulkintojani. Dokumentaatio on saanut jatkoa artikkelin kirjoitusprosessin myötä.

\section{KORUKIELIOPPI KORUTAITEENA}

Työni alkoi siis haastattelujen tekemisellä ja purkamisella. Vasta sen jälkeen aloin pohtia, miten käyttäisin tätä kerättyä aineistoa. Aluksi ei ollut mitenkään selvää, että valitsisin työni konkreettiseksi toteutustavaksi juuri korut. Kävin läpi erilaisia mahdollisuuksia ja suunnittelin muun muassa installaatioiden rakentamista. Kaikissa suunnitelmissa tuntui kuitenkin olevan vikana staattisuus. Ne myös veivät työtä liian kauas alkuperäisestä aiheestaan, Tyttöjen Talon henkilökunnasta. Korut alkoivatkin kiinnostaa minua henkilökohtaisuutensa ja lähelle tulevuutensa vuoksi. Korua käytetään sekä vartalon jatkeena että kantajansa mielen jatkeena ja ilmaisijana. (Ikonen 2004, 65.)

Korut ovat tietyllä tavalla rajatapaus. Ne luetaan toisaalta käyttöesineiden, toisaalta muotoilun, toisaalta kuvataiteen piiriin - toisaalta korun käsite sulkee sisäänsä edelleen myös paljon muuta: amuletti, rihkamakoru ja vaurautta osoittava timanttisormus ovat koruja siinä missä taideteoskin. Useissa koruissa on sekä arkisuuden että vierauden piirteitä. (Ikonen 2004, 84-85.) Itse käytän korutaidetta enemmänkin tulkitsevien tavoitteitteni mahdollistajana. Työni tavoite ei siis ollut sinänsä valmistaa mahdollisimman taidokkaita koruja tai esimerkiksi kehittää korunteon tekniikoita. Toisin sanoen pyrkimyksenäni ei ollut osallistua korutaiteelliseen diskurssiin, vaikka 
näinkin kenties tuli jossain mielessä tapahtuneeksi. Kuitenkin on selvää, että pyrin valmistamaan korut niin, että niiden muoto on sisällön kanssa yhtä.

On myös hyvä huomata, että koru on sukupuolittunut ja sukupuolittava esine. Vaikka koruja on valmistettu ja valmistetaan myös miehille, niitä käyttävät nykyään selvästi useammin naiset. Miesten ja naisten korut ovat usein myös varsin erilaisia. Naisten koruille on tyypillistä muun muassa runsaampi koristeellisuus, kun taas miesten korut ovat esimerkiksi massiivisempia. Koruilla ja koruttomuudella sukupuolta voi näin korostaa tai häivyttää. Korukieliopin koruissa hain usein tietoisesti feminiinisyyttä tukevia ja välittäviä materiaaleja ja muita elementtejä, mutta pyrin saamaan nämä elementit vastaamaan sitä, mitä haastateltavat itse naiseudestaan minulle kertoivat ja miten he naiseuttaan määrittelivät. Itsekin määrittelin - ja minulle myös ulkoapäin määriteltiin - korujen tekemiseni olevan sinänsä feminiinistä, varsinkin kun käyttämäni tekniikat olivat kevyitä enkä esimerkiksi työstänyt materiaaleja koneellisesti.

Lopullisin syy siihen, miksi valitsin korut työni konkreettiseksi ilmaisumuodoksi, oli korun rooli merkitysten kantajana. Koruun yleensä liittyy ajatus siitä, että sitä kannetaan fyysisesti, mutta sen avulla voidaan esittää myös vähemmän konkreettisia asioita, kuten kantajan esteettisiä arvostuksia, muistoja, menneisyyttä ja arvoja. (Ikonen 2004, 94). Tuntui kulttuurintutkimuksellisestikin hedelmälliseltä työskennellä sellaisen tuotoksen parissa, joka olisi itsessään kulttuurisia merkityksiä kantava ja ilmentävä. Tutkimuskohteenani oleva kerronta on mielestäni rinnastettavissa koruun siinä, että molemmat ovat toisaalta yhteisöllistä kommunikaation välineitä, toisaalta sisältävät yksilöllisiä merkityksiä. Kertomisen on oltava kulttuurisesti ja henkilökohtaisesti ymmärrettävää ja mielekästä. (Ks. esim. Aro 1996, 47; Siikala 1984, 19.) Samalla lailla voi toimia myös koru.

\section{KORUKIELIOPPI, ESINE JA ESINEISTÄMINEN}

Korukielioppiin kuuluu siis immateriaalisia osia, mutta myös kysymys konkreettisista materiaaleista ja työtavoista on keskeinen erityisesti itse korujen kohdalla. Kuten edellä mainitsin, korutaiteelliseen diskurssiin osallistuminen ei ollut tavoitteenani, joten sitä kautta en lähtenyt materiaalivalintojani pohtimaan. Pikemminkin minua kiinnosti luoda koruihin muistumia kuvataiteen tiettyihin suuntauksiin, erityisesti arte poveraan, jossa käytettiin arkisia esineitä teoksiin, joiden visuaalinen ilme saattoi lopulta olla varsin tuhlailevakin. Koruihin käytinkin erityisesti kierrätettyjä esineitä ja korunosia.

Muotoilijan ammattitaitoa on hyödyntää materiaaliin kuuluvia mielikuvia ja muistoja (Ikonen 2004, 59). Folkloristi-kuvataiteilija ei omaa samaa ammattitaitoa, mutta materiaaleja, tässä tapauksessa esineitä, on mahdollista tarkastella myös kulttuurintutkimuksen näkökulmasta, joka lopulta ei välttämättä ole kovin erilainen. Kuten Ilmari Vesterinen toteaa, esineet ovat "esinepelin nappuloita". Tällä Vesterinen tarkoittaa sitä, että esineen merkitys tulee esiin siinä, miten ihminen sillä pelaa: muodostaa siihen suhteen, luo sille kertomuksen. Ihminen myös investoi esineisiinsä minuuttaan. (Vesterinen 2001.) Päivikki Suojanen on kirjoittanut esineistä folkloristi- 


\section{TAITEILJUUS JA TUTKIJUUS TUTKIVASSA TAIDEPROSESSISSA}

sesta näkökulmasta. Hän rinnastaa esineet vahvasti folkloristiikan tutkimuskohteiden kanssa ja pitää kulttuurissa tapahtuvaa symboloimista ja toistoa esineistämisenä (Suojanen 2001,217). Näin ajateltuna esineitä on mahdollista tarkastella hyvinkin samoista lähtökohdista henkisten kulttuurituotteiden kanssa.

Keskeisiä valitsemissani esineissä olivat niiden tuottamat naiseuden esitykset. Osa valitsemistani esineistä oli tulkittavissa itsessään jollain tavalla feminiiniseen viittaaviksi. Käytin esimerkiksi keittiön tarvikkeita, nappeja ja vanhoja meikkirasioita. Toisissa taas itse käytin esinettä viittaamaan johonkin feminiiniseen, kuten heijastinta symboloimaan suojan antamista tai ketjua kuvaamaan liittymistä. Joissain koruissa kirjoitin merkityksiä myös esineiden väreillä ja kuvioilla. Käyttämieni esineiden, muotojen ja värien symboliikka ja merkityskieli ei ole mitenkään vaikealukuista tai esoteerista. Mistään suoraviivaisestakaan merkitysten esittämisestä ei silti ole kysymys. Olen pyrkinyt merkitysyhdistelmillä luomaan myös uusia tapoja nähdä tuttu symboli. Esimerkiksi lautasliinarenkaista valmistetut kirkkovenesymbolit ovat hyvin kauniin ja hauraan näköisiä, mikä poistaa symboliin liittyvää halventavaa sisältöä. Medaljongeiksi työstetyt meikkirasiat antavat myös suojaa, eivät vain kuvasta kauneusihanteita.

Koostin korut niin, että niiden tuottamat merkitykset vastaisivat mahdollisimman hyvin haastatteluissa tuotettuja. Pidän tätä mahdollisena, sillä vaikka esineen sisältämä merkitys on tulkinnanvarainen, se ei ole kuitenkaan mielivaltainen. Esineiden ja muidenkin visuaalisten elementtien sisältämiä merkityksiä voi hallita siinä missä kieltäkin. Esineiden käyttö - sanojen sijaan - tulkinnan kielenä on siis mahdollista, mutta tutkimustekstiin nähden kuvallinen tai korullinen tulkinta on toki elämyksellisempää ja arvaamattomampaa. Viestien välittäminen ei ole niin hyvin hallittavissa kuin verbaalisessa ilmaisussa. Visuaalinen tulkinta, esineet ja taideteokset, avaavat tavattoman monia tulkinnan mahdollisuuksia, joita itse tekijänä ei ole huomannut tai tarkoittanut. On mahdollista, että osa näistä voi olla ristiriidassa tekijän tarkoitusten kanssa. Omassa projektissani kuitenkin koin niin haastateltavien kuin työn katsojienkin lisätulkinnat vain rikastuttavina. Kuvataiteellisesti esitetty tulkinta ei voine ollakaan autoritaarinen tai lopullinen; kuvataiteen teokseen kuuluu oleellisesti sen vastaanotto.

Työni pitäminen pienimuotoisena auttoi minua välttämään joitakin karikoita; Korukielioppi ei edes yritä välittää kuin osia mahdollisista tulkinnoista. Tämä oli luonnollisestikin mahdollista siksi, että kyseessä oli joka tapauksessa taideteos, jolta tämän kattavampaa esitystä ei edes edellytetä.

\section{KORUKIELIOPPI TUTKIJA-TAITEILIJAN KERTOMUKSENA}

Tutkimusteksti on aina myös tutkijan narratiivia tapahtuneesta, kuullusta ja nähdystä. Korukielioppi demonstroi tätä tutkimuksen piirrettä omalaatuisella tavalla, tuomalla sen visuaaliseen muotoon. Voisin verrata itseäni vaikkapa taiteen tohtoriksi väitelleeseen mutta peruskoulutuksensa folkloristiikassa saaneeseen Eija Timoseen, joka määrittelee taiteilijuuttaan kahdella termillä. Ensimmäinen näistä on "iteilijä", ITE-taiteilija (Timonen 2004, 168). ITE-taiteilijalla kuitenkin tavallisesti ymmärretään itseoppinutta 
taiteilijaa, joten määritelmä on Timosen tapauksessa ongelmallinen, ja itselleni kuvataiteen muodollisen koulutuksen saaneena se on jokseenkin sopimaton.

Toinen termi on hedelmällisempi ja valaisee myös työtäni tutkija-taiteilijan kertomuksena. Timonen kutsuu itseään bricoleuriksi, bricolagen tekijäksi, millä hän viittaa Claude Lévi-Straussin (1966) lanseeraamaan termiin. Bricolagella tarkoitetaan kulttuurissa saatavilla olevien ainesten, aineellisten tai henkisten, yhdistelyä ja ottamista uuteen käyttöön. Timosen taiteellisen työskentelyn aineistona on arkistoitu kertomusperinne, jota hän työstää folkloristin ammattitaitoa hyödyntäen. On mahdollista nähdä myös oma työni jonkinlaisena bricolagena, jossa kulttuuriset merkitykset valjastetaan uuden taideteoksen käyttöön, sillä minä käytän bricolagessa hyväkseni kulttuurituotteiden tuntemustani.

Bricolagen tekeminen siis edellyttää kulttuurista luovuutta ja asiantuntemusta. Kulttuurin elementtejä ei voi käyttää mielivaltaisella tavalla, vaan bricolage tehdään aina järjestelmän sisällä (mts. 19). Lévi-Strauss kuitenkaan ei alun perin viittaa bricolagella sen paremmin tieteeseen kuin taiteeseen. Bricolagen tekemisen taito on pikemminkin yleistä kulttuurista kompetenssia kuin kulttuurintutkijan erityisosaamista. Näenkin sen käytössä ongelmia, mutta myös mahdollisuuksia. Kulttuurituotteiden käyttäjänä niiden tutkija on osin eri asemassa; minullekin on ollut täysin luontevaa tuoda työhöni historiallisia ja vieraiden kulttuurien aineksia, jotka laajentavat käytössä olevaa kulttuurituotteiden järjestelmää huomattavasti. Lévi-Strauss erottaa tieteen ja bricolagen tekijät toisistaan sillä perusteella, että jälkimmäinen toimii järjestelmän sisällä, ensimmäinen tarkastelee sitä ulkopuolelta (ja pyrkii vaikuttamaan siihen). Toisaalta on mielenkiintoista ajatella kulttuurintutkimusta yleensäkin prosessina, jossa yksittäisistä kulttuurin tuotteista yhdistellään omassa tutkijan ja tieteenalan käsitejärjestelmässämme mielekkäitä kokonaisuuksia; siinä mielessä tutkijakaan ei suinkaan ole järjestelmän ulkopuolella. Tämä on nähdäkseni oman työni tapauksessa hyvin osuva näkemys. Bricolage voidaan nähdä tapana työstää aineiston kulttuurisista kertomuksista uusi, yhtä lailla kulttuurisesti perusteltu ja lukukelpoinen kertomus.

Lévi-Strauss erottaa bricolagen myös taiteesta. Bricolage on pikemminkin toimintaa, joka kulttuurissamme mielletään enemmänkin harrastukseksi ja ajanvietteeksi. Kuitenkin Lévi-Straussin mukaan taiteilija voi työssään olla niin bricolagen kuin tieteenkin tekijä. Bricolage on tietynlaista järjestyksen luomista kulloinkin käsillä olevaan heterogeeniseen materiaaliin. (Lévi-Strauss 1966, 22, 33.) Minun työni kaltainen taideprojekti muistuttaakin bricolagea enemmän kuin vaikkapa perinteinen öljyvärimaalaus.

\section{ONKO KUVATAITEESTA TUTKIMUSMENETELMÄKSI?}

Korukieliopin prosessin aikana olen saanut joitakin uusia kysymyksiä mutta myös kouriintuntuvia vastauksia alkuperäiseen kysymykseeni siitä, mitä mahdollisuuksia kuvataiteella on tuottaa tietoa tutkimuksessa, jonka varsinainen kohde ei ole taideteos. Ensimmäinen suuri mahdollisuus on, se että tiedon esittämisen muoto on soveltuvampi 


\section{TAITEILJUUS JA TUTKIJUUS TUTKIVASSA TAIDEPROSESSISSA}

(vrt. Anttila 2005, 101), koska sillä tavoitetaan tutkittavat ihmiset henkilökohtaisemmin ja elämyksellisemmin. Samalla pystytään säilyttämään dialogisuus loppuun asti.

Toinen mahdollisuus liittyy kuvallisen esityksen monitulkintaisuuteen. Korukielioppi hyödyntää keskeisesti kulttuurista tietoa; tietoa jota liittyy toisaalta haastattelujen teemoihin, erityisesti sukupuoleen, toisaalta korujen materiaaleihin. Näen itseni kulttuuristen merkitysten havaitsijana, kanavoijana ja ylöskirjaajana. Kuten aiemmin totesin, esineiden ja taideteosten sisältämät viestit ovat elämyksellisiä ja moniulotteisia, kun taas tieteellisen kirjoittajan tavoitteena on päinvastoin minimoida monitulkintaisuuden mahdollisuutta ja käyttää mahdollisimman täsmällistä kieltä. Juuri tästä syystä näen kuvataiteellisen osuuden tuoneen huomattavaa lisäarvoa verrattuna vaikkapa aluksi tekemääni puhtaasti tieteelliseen analyysiin (Nitovuori 2006a). Tyttöjen Talon työntekijöiden ja muiden Korukielioppiin tutustuneiden kanssa dialogissa tuotetut uudet tulkinnat ja näkökohdat eivät olisi välttämättä syntyneet ilman kuvallisen ilmaisun avaamia uusia perspektiivejä.

Perinteisesti tutkimustiedolta on kylläkin edellytetty verbalisoitavuutta, mutta muutkin tiedon representaation tavat ovat tulleet yhä hyväksyttävämmiksi (Anttila 2005, 52-55). Myös kuvataiteilijana tehtäväni on hallita ja perustella sitä, miten käytän visuaalista ainesta. Tässä vaaditaan samaa kurinalaisuutta kuin tutkijan työssä, lisäksi molempien osa-alueiden, niin tutkimuksen kuin taiteenkin, muodollinen hallinta tulee todelliseen tarpeeseen. Kaikin osin en (osin yllätyksekseni) kokenut Korukielioppia tehdessäni suurtakaan eroa tutkijanrooliini nähden. Suurimpana siltana ja mahdollisuutena näen sen, että niin tutkijana kuin kuvataiteilijanakin analysoin tekstistä toistuvia teemoja ja kuvaan niitä jollakin käytettävissä olevalla kielellä, oli se sitten tieteen, taiteen, korun tai esineen kieli.

Taiteellisen esityksen moniulotteisuuden kääntöpuolena on, että tulkintoja on hyvin vaikea pysäyttää mihinkään eikä varsinaisia lopullisia tuloksia ole mahdollista esittää. Kuten Graeme Sullivan toteaa, taiteellisen tutkimuksen yleisenä edellytyksenä on, että tutkimuksen tavoitteet liittyvät enemmän ilmiön ymmärtämiseen kuin tyhjentävään selittämiseen. Sullivan esittää, että taiteellisen tutkijan tulisi suuntautua todennäköisyyden (engl. plausibility) sijaan mahdolliseen (engl. possibility), mikä mahdollistaa luovat ratkaisut ja tulkinnat. Tärkeämpää kuin ilmiön tilastollinen merkittävyys on sen mielekkyys kulttuurissa. Sullivan muistuttaa myös taideinstituutioon oleellisena osana kuuluvasta keskustelun, kritiikin ja julkisen tulkitsemisen perinteestä, joka myös asettaa taiteen teoriat ja käytännöt jatkuvaan empiiriseen testiin ja lisää taiteellisen tutkimisen luotettavuutta. (Sullivan 2005, 48.) Sullivan nimeää tällaisen tutkivan taiteen tekijän rooliksi taiteilija-teoreetikon (engl. artist-theorist), jolla on kompetenssia hyödyntää sekä visuaalista, kuviin tallentunutta tietoa että tieteen piirissä tuotettuja teorioita ja käytäntöjä.

Parhaiten kuvataiteellinen työskentely tutkimusmetodina näyttääkin sopivan lisäarvon tuottamiseen sellaisessa tutkimuksessa, jossa tulkintojen määrän ei tarvitsekaan olla lopullinen. Tällä tarkoitan erityisesti hermeneuttisesti suuntautunutta tutkimusta, jonka tavoitteena on ymmärtävyys ja tulkitsevuus (Granö 2000, 24-32). Puhun lisäarvosta, koska nähdäkseni kuvataiteellinen työskentely on tutkimusmenetelmänä 


\section{LIISA-MARIA NitovUORI}

hedelmällisin yhdistettynä muihin metodeihin, jolloin erilaiset tiedon tuottamisen tavat täydentävät toisiaan.

Minusta tutkiva, analyyttinen ja keskusteleva rooli on ollut suhteellisen helppo ottaa osaksi taiteilijuutta varsinkin, kun taide on joka tapauksessa avautunut siihen suuntaan. Tieteessäkin ei-autoritaarista, dialogista tutkijuutta on lanseerattu jo melko pitkään. Silti, kun prosessini on ollut hankala, sitä on tuottanut pikemminkin tutkijan kuin taiteilijan rooli. Yhtenä ongelmana koen luovan kuvallisen esityksen vierauden tieteessä. Tiedon järjestäminen on kuitenkin itsessään esteettinen prosessi (vrt. LéviStrauss 1966). Toisena ongelmana näen valtakysymykset: oikeus tuottaa tietoa on valtaa antava ja siksi myös kiistelty. Kun taidetta määritellään tiedon tuottajaksi, se myös tunkeutuu alueelle, joka on perinteisesti varattu tieteelle. Muun muassa naistutkimuksessa ja taidekorkeakoulujen tutkimustyössä on tätä asetelmaa pyritty purkamaan, mutta jännitteetöntä ei tutkivan taideprosessin läpikäyminen ole.

\section{LÄHTEET}

\section{Tutkimusaineistot}

Haastattelut:

Liisa-Maria Nitovuoren tekemät haastattelut Tyttöjen Talossa Helsingissä. Haastattelut tekijän hallussa. Nimiä ei ole muutettu.

— Ninni, synt. 1974. Haastateltu 17.6.2005.

— Paula, synt. 1974. Haastateltu 17.6.2005.

- Henna, synt. 1978. Haastateltu 7.9.2005.

— Mari, synt. 1968. Haastateltu 9.9.2005.

— Laura, synt. 1971. Haastateltu 9.9.2005.

— Susanna, synt. 1974. Haastateltu 23.9.2005.

\section{Seminaariesitelmät ja työpaperit}

NITOVUORI, LIISA-MARIA 2006a: Narratives of Gender in Youth Work - Case: The Girls' House in Helsinki. Paper presented at The 9th Nordic Youth Research Information Symposium at Södertörns University College, Jan 132006 [online]. <http://webappl. web.sh.se/C1256CD200369F7E/0/4B433E5F44710CB4C12570E40043D8AA/ \$file/Liisa-Maira\%20Nitovuori.rtf > [10.10.2007.]

— 2006b: Taiteilijuus ja tutkijuus tutkivassa taideprosessissa. - Esittäjä tekijänä, taitaja taiteilijana -kollokvio. Sibelius-Akatemia, Helsinki 27.-28.10.2006.

SCRIVENER, STEPHEN 2002: The Art Object Does Not Embody a Form of Knowledge. Working Papers in Art and Design 2 [online]. <http://www.herts.ac.uk/ artdes/research/papers/wpades/vol2/scrivenerfull.html $>$ [10.10.2007.] 


\section{TAITEILJUUS JA TUTKIJUUS TUTKIVASSA TAIDEPROSESSISSA}

\section{Kirjallisuus}

ANTTILA, PIRKKO 2005: Ilmaisu, teos, tekeminen ja tutkiva toiminta. Hamina: Akatiimi. ARO, LAURA 1996: Minä kylässä. Identiteettikertomus haastattelututkimuksen folklorena. Suomalaisen Kirjallisuuden Seuran Toimituksia 650. Helsinki: Suomalaisen Kirjallisuuden Seura.

GRANÖ, PÄIVI 2000: Taiteilijan lapsunden kuvat. Lapsuusja taide samassa hetkessä. Helsinki: Taideteollinen korkeakoulu.

IKONEN, PETTERI 2004: Arjen trilogia. Korutaide taiteen tekemisen ja kokemisen välineenä. Helsinki: Taideteollinen korkeakoulu.

KANTONEN, LEA 2005: Teltta. Kobtaamisia nuorten taidetyöpajoissa. Helsinki: Like; Taideteollinen korkeakoulu.

KESTER, GRANT 2004, Conversation Pieces. Community and Communication in Modern Art. Berkeley: University of California Press.

LAURENT, LINA 2004: What More Can We Do? Multicultural Girl Work in Practice. Developing a Multicultural Action Plan for the Girls' House, A Meeting Place for Girls and Young Women in Helsinki. Helsinki: Helsinki City Urban Facts Office.

LÉVI-STRAUSS, CLAUDE 1966: The Savage Mind. Chicago: University of Chicago Press.

NITOVUORI, LIISA-MARIA 2002: Tyttöjen Talo. Kumppanuushankkeen arviointi. Helsinki: Kalliolan Nuoret ry.

SAARIKOSKI, HELENA 1996: Open Conversation as a Research Interview Method. - Helve, Helena \& Bynner, John (eds.), Youth and Life Management. Research Perspectives. Helsinki: Yliopistopaino

SIIKALA, ANNA-LEENA 1984: Tarina ja tulkinta. Tutkimus kansankertojista. Suomalaisen Kirjallisuuden Seuran Toimituksia 404. Helsinki: Suomalaisen Kirjallisuuden Seura.

SULLIVAN, GRAME 2005: Art Practice as Research. Inquiry in the Visual Arts. Thousand Oaks: Sage Publications.

SUOJANEN, PÄIVIKKI 2001: Esine ja esineistäminen uskontotieteessä ja folkloristiikassa. - Vesterinen, Ilmari \& Lönnqvist, Bo (toim.), Pandoran lipas. Virvatulia esineiden maailmasta. Tietolipas 179. Helsinki: Suomalaisen Kirjallisuuden Seura.

TIMONEN, EIJA 2005: Perinteestä mediavirtaan. Kansanperinteen munntuminen arkistomuistiinpanoista lastenkulttuuriksi. Tietolipas 209. Helsinki: Suomalaisen Kirjallisuuden Seura.

VASENKARI, MARIA 1996: Mitä se sanoo? Mistä se kertoo? Dialoginen näkökulma kenttätutkimusaineiston tuottamiseen. - Hovi, Tuija \& Tarkka, Lotte (toim.), Uskontotiede - folkloristiikeka. Kirjoituksia opinnäytteistä. Etiäinen 3. Turku: Turun yliopisto.

VESTERINEN, ILMARI 2001: Esinepeli. - Vesterinen Ilmari \& Lönnqvist Bo (toim.), Pandoran lipas. Virvatulia esineiden maailmasta. Tietolipas 179. Helsinki: Suomalaisen Kirjallisuuden Seura.

Liisa-Maria Nitovnori: Korukielioppi < http://mmw.elore.fi/arkisto/2_07/korukielioppi.ppt.>

Filosofian maisteri Liisa-Maria Nitovuori on folkloristiikan jatko-opiskelija Helsingin yliopistossa. 